\title{
Comparison of the weathering behavior of a very high strength concrete with that of a standard concrete
}

\section{(Comparação do comportamento climatizado de um concreto de alta resistência com o de um concreto padrão)}

\author{
A. Blandine*, B. Essaïd, G. Bernard \\ Centre SPIN (Sciences des Processus Industriels et Naturels), Ecole Nationale Supérieure des Mines de \\ Saint-Etienne, 158 cours Fauriel, 42023 Saint-Etienne Cedex 2, France \\ bilal@emse.fr,guy@emse.fr
}

\begin{abstract}
We studied the weathering process of a very high strength concrete (VHSC) and compared it with that of a usual concrete. VHSC has compressive strengths much above $100 \mathrm{MPa}$ after seven days of curing. The compressive strength is increased by lowering the value of the water/cement ratio and by improving the particle size distribution of the numerous residual anhydrous grains of clinker and of the quartz aggregates. A proportion of $15 \%$ of the cement is replaced by non-condensed silica fume, which consists of spherical particles of amorphous silica, $0.1 \mu \mathrm{m}$ in diameter. This has the advantage to fill the space between clinker particles. Another advantage is to densify the interfacial zone between cement paste and aggregates. Afters 28 days of curing, the VHSC samples consist of quartz aggregates and residual anhydrous clinker particles linked to each other with a paste mainly composed of calcium silicate hydrate (C-S-H). Samples of VHSC were immersed in continuously renewed distilled water under inert atmosphere. After two months of exposure, chemical, mineralogical and textural changes have occurred in a superficial zone. The depth of the degraded zone is $300 \mu \mathrm{m}$. This value is much lower than the depth of the degraded zone formed in an usual mortar $(800 \mu \mathrm{m})$ or in a common paste $(1500 \mu \mathrm{m})$ leached in the same condition. At the surface of the weathered samples of VHSC, the anhydrous clinker particles have dissolved and the resulting holes of $10 \mu \mathrm{m}$ diameter remained empty. At the frontier between the safe core and the weathered superficial zone, the holes resulting from the dissolution of clinker particles were filled with secondary C-S$\mathrm{H}$. As a conclusion, the low porosity of VHSC is a benefit for the compressive strength but also for the durability. The presence of numerous anhydrous clinker particles is not a problem.
\end{abstract}

Keywords: concrete, weathering.

\section{Resumo}

O processo de climatização de um concreto de alta resistência mecânica (VHSC) foi estudado e comparado com o de um concreto comum. O concreto VHSC apresenta resistência à compressão muito maior que $100 \mathrm{MPa}$ após sete dias de cura. A resistência à compressão aumenta com a diminuição do valor da relação água/cimento e melhorando a distribuição de tamanho de partícula dos inúmeros grãos anidros residuais de clínquer e dos agregados de quartzo. Uma proporção de 15\% do cimento é substituída por resíduo de sílica não condensada, que consiste de partículas esféricas de sílica amorfa de 0,1 um de diâmetro, com a vantagem de preencher o espaço entre as partículas de clínquer. Outra vantagem é densificar a zona interfacial entre a pasta de cimento e os agregados. Após 28 dias de cura, as amostras de concreto VHSC consistem de agregados de quartzo e resíduos de partículas anidras de clínquer ligadas umas às outras com uma pasta composta principalmente de hidrato silicato de cálcio (C-S-H). Amostras de concreto VHSC foram imersas em água destilada continuamente renovada sob atmosfera inerte. Após dois meses de exposição, ocorreram mudanças químicas, mineralógicas e texturais em uma zona na superficie. A profundidade da zona degradada foi $300 \mu \mathrm{m}$. Este valor é muito menor que a profundidade da zona degradada formada em uma argamassa comum $(800 \mu \mathrm{m})$ ou em uma pasta comum $(1500 \mu \mathrm{m})$ submetida à mesma condição. Na superficie das amostras climatizadas de concreto VHSC, as partículas anidras de clínquer dissolveram e o vazio resultante de 10 um de diâmetro permaneceu vazio. Na fronteira entre o interior isolado e a zona climatizada da superficie os vazios resultantes da dissolução das partículas de clínquer foram preenchidos com C-S-H secundário. Como conclusão, a baixa porosidade do concreto VHSC foi benéfica para a resistência à compressão e também para a durabilidade. A presença de inúmeras partículas anidras de clínquer não resultou em problema.

Palavras-chave: concreto, climatização.

\section{INTRODUCTION}

The aim of this research is to compare the weathering behavior of a very high strength concrete (VHSC) with

\footnotetext{
*Present address : Centre de Recherche, Lafarge, 95 rue du Montmurier,
} BP 15, 38291 St Quentin Fallavier Cedex, France that of a standard one called UC ("Usual Concrete"), and to correlate the characteristics of the weathering with the preparation methods of both concretes. In addition to its properties of effective mechanical resistance, the VHSC is supposed to present a durability superior to mortars and Portland cement concretes. The VHSC is very little porous 
indeed, because it is formulated with a low water/cement ratio and contains silica fume particles. Besides, the silica fumes play the role of pozzolanic agent. The material usually contains very little Portlandite, a very soluble phase. The low porosity and the absence of Portlandite contribute to make the VHSC a material resistant to the weathering by water. Several authors have been interested in concrete durability [1-10]. Our experimental device and the conditions for our experiments are different from that of the mentioned authors who mostly studied concrete durability in extreme conditions.

\section{MATERIALS AND METHODS}

The behavior of samples of the very high strength concrete was observed after it was immersed during two months in a reactor filled with water with a continuous renewal of the solution. After 28 days of ripening, we characterized the VHSC and UC samples by the following methods: assessment of porosity by capillary absorption, balance of hydrates and of the residual anhydrous minerals by X-ray diffraction (XRD), observation of phase texture under the scanning electron microscope (SEM), and determination of the chemical composition of phases by the electron microprobe.

The same weathering procedure has been applied for the lixiviation of the UC mortar and that of the VHSC. Mortar circular tablets of $5 \mathrm{~cm}$ diameter and $5 \mathrm{~mm}$ thickness are dived in a reactor filled with $6 \mathrm{~L}$ of distilled water. The solution of the reactor is agitated by a magnetic agitator. It is continuously renewed by a drip of distilled water. This circuit in continuous is assured by a kettle that distils the overflow of the reactor. The kettle serves to assure the regular renewal of the solution and to concentrate elements in traces freed by the weathered cement. As we are only interested in the major elements, withdrawals are done directly in the reactor where the measured elements are in sufficient concentration.

During the two months of exposure, the regular withdrawals of solution are done in the reactor. The $\mathrm{pH}$ and the content in $\mathrm{Ca}, \mathrm{Si}, \mathrm{Al}, \mathrm{Mg}, \mathrm{Na}, \mathrm{K}$ and in sulphates have been measured for every withdrawal. After two months of weathering, the VHSC and UC samples have been analyzed by DRX, SEM and microprobe in order to establish their weathering degree.

The usual concrete UC (CPA CEM I 52.5 PMS ES) has been flowed in cylinders of polyethylene of $5 \mathrm{~cm}$ of diameter. At the end of $24 \mathrm{~h}$ of hydration, water has been added in cylinders for a ripening of 28 days. The hydrated phases formed and the residual anhydrous phases in the sample after 28 days are the $\mathrm{CSH}$, ettringite, calcium monosulfoaluminate, vaterite, hydrogarnet, belite $(\beta$ $\left.\mathrm{C}_{2} \mathrm{~S}\right)$ and brownmillerite $\left(\mathrm{C}_{4} \mathrm{AF}\right)$. The presence of vaterite

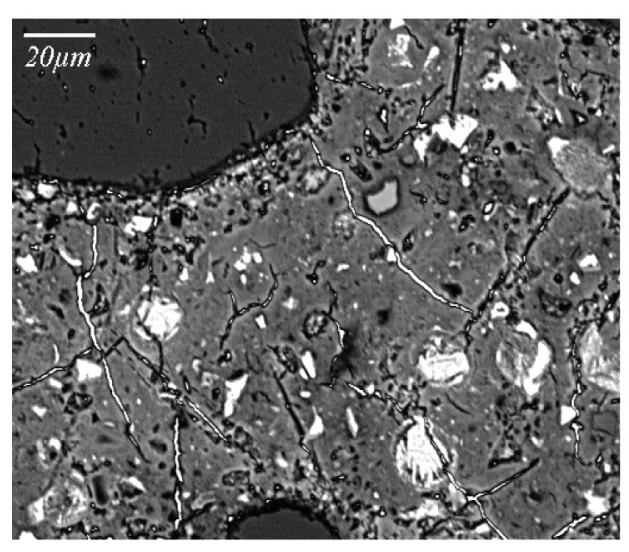

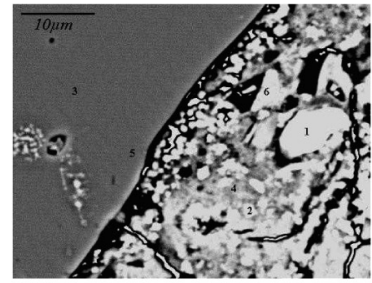

$\mathrm{Ca}$

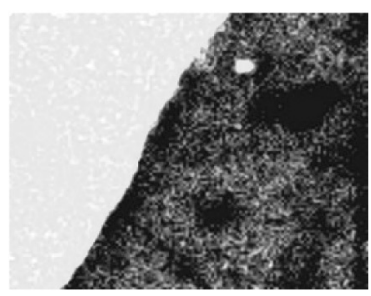

$\mathrm{Si}$

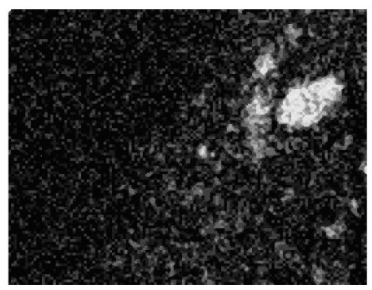

Al

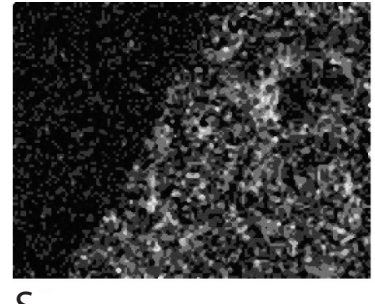

$\mathrm{S}$

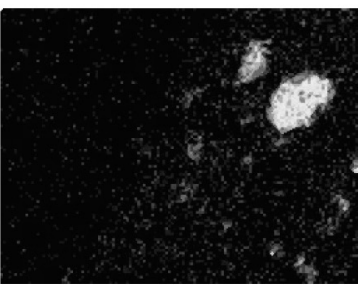

Fe

Figure 1: Observation of a usual concrete UC section by SEM and distribution map of Ca, S, Si, Al and Fe.

[Figura 1: Observação por microscopia eletrônica de varredura de uma secção comum de concreto UC e mapa de distribuição de Ca, S, $\mathrm{Si}$, Al e Fe.] 

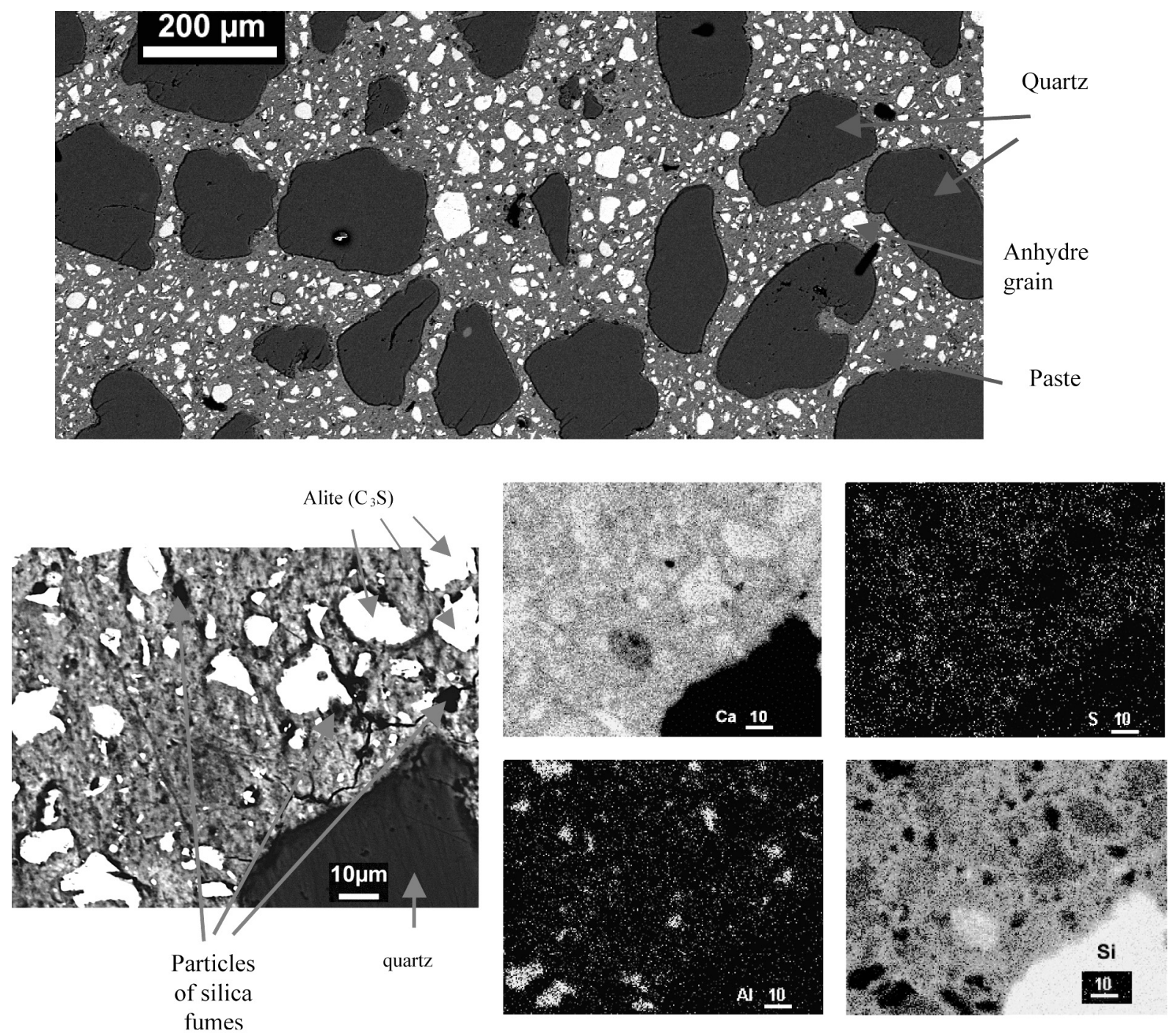

Figure 2: Observation of a VHSC section by SEM and distribution map of $\mathrm{Ca}, \mathrm{S}, \mathrm{Al}$ and $\mathrm{Si}$.

[Figura 2: Observação por microscopia eletrônica de varredura de uma secção de VHSC e mapa de distribuição de Ca, S, Al e Si.]

indicates a light carbonatation. DRX data are confirmed by observations under the SEM. The mass of hydrates is constituted in variable proportions of portlandite, the $\mathrm{CSH}$, hydrogarnet, ettringite and calcium monosulfoaluminate. belite $\left(\beta-\mathrm{C}_{2} \mathrm{~S}\right)$ and brownmillerite $\left(\mathrm{C}_{4} \mathrm{AF}\right)$ are also present. The map of distribution of the calcium indicates that the interface between quartz aggregates and the paste is essentially constituted of portlandite (Fig. 1).

The chemical composition of UC is characterized by a high $\mathrm{Si} / \mathrm{Ca}$ ratio and a low sulphur content. The $\mathrm{C} / \mathrm{S}$ ratio of the CSH lies between 0.8 and 2.3 for $\alpha, \beta$ and $\gamma$ types of CSH $[6,11]$. But two important populations distinguish themselves, one with $\mathrm{C} / \mathrm{S}=1.2$ and the other with $\mathrm{C} / \mathrm{S}=1.4$ corresponding to $\beta$ type. ettringite and calcium monosulfoaluminate are present in lower quantity.

The very high strength concrete (VHSC) contains particles of silica fumes that bring modifications to the microstructure and the nature of hydrates when compared to the UC. The presence of particles of silica fumes permits to accelerate the hydration of the cement and to increase the density of hydrates. The particles of silica fumes fill a part of voids around the grains of clinkers and the quartz aggregates. They do not remain inert in the hydrated cement. They have pozzolanic properties; they react with the portlandite resulting from the hydration of the belite $\left(\mathrm{C}_{2} \mathrm{~S}\right)$ and the alite $\left(\mathrm{C}_{3} \mathrm{~S}\right)$ to form some CSH [12].

The samples of VHSC have been flowed in cylinders of polyethylene of $5 \mathrm{~cm}$ of diameter. After $24 \mathrm{~h}$ of hydration, the water has been added in cylinders for a ripening of 28 days. Because of the low water/cement ratio, the hydration of the mixture (cement and silica fumes) is incomplete. Apart from the presence of residual alite $\left(\mathrm{C}_{3} \mathrm{~S}\right)$ clinker phase, we have the same phases as already observed in the UC. The XRD intensity for portlandite is very weak in comparison with that of the UC (Fig. 2).

Grains of quartz and the residual anhydrous grains of 
alite $\left(\mathrm{C}_{3} \mathrm{~S}\right)$, belite $\left(\mathrm{C}_{2} \mathrm{~S}\right)$ and brownmillerite $\left(\mathrm{C}_{4} \mathrm{AF}\right)$ are dispersed in a paste. The residual anhydrous grains are numerous and seem to play the role of nuclei for aggregates as do the quartz grains. Map of $\mathrm{Ca}, \mathrm{Si}, \mathrm{Al}$ and $\mathrm{S}$ distribution, learn us that about these particles that did not react. We do not observe difference of texture or chemical composition in the interface zone between the quartz grain with the paste and the remainder of the paste. Notably, we do not observe preferential precipitation of portlandite in the interface zone, contrary to what we had seen for the UC.

The CSH of VHSC has a C/S ratio lying between 0.9 and 1.5 this interval corresponds to the $\beta$ type of CSH. The VHSC contains very low portlandite contents.

\section{RESULTS AND DISCUSSION}

After two months in the reactor, the sample of UC appears strongly weathered. The quartz aggregates, that are not weathered, indicate us the initial thickness of the sample. We observe between these grains that a part of the paste remains. For several observations the departure of matter is made on $125 \mu \mathrm{m}$ thickness. A dark grey and porous zone, of thickness of 150 to $200 \mu \mathrm{m}$, formed in the surface of UC. The sample of VHSC appears less damaged. As for the UC, a grey dark and porous zone formed in the surface of VHSC and has a thickness of $70 \mu \mathrm{m}$ on average. We do not observe an important loss of the paste. The mineralogical composition of the different zones is established by XRD. The external surface of the sample is analyzed rightly after the end of the experience, when the sample is dry. Then, the sample is eroded on a rotating tray with use of silicon carbide powder and oil. After erosion, sample thickness remains of about $100 \mu \mathrm{m}$. An analysis is then made by XRD on every new surface obtained after wear. This was done until one gets a similar diffractogram to that of the initial sample. This partial wear permits to progress step-by-step in the sample. The new gotten surfaces correspond, according to the advancement of wear, to the observed zones. Fig. 1 and Fig. 2 give information about the non-weathered UC and VHSC concretes (SEM observation and distribution maps of chemical elements). Fig. 3 gives large-scale SEM photographs allowing comparing the weathering of both UC and VHSC concretes. Fig. 4 and Fig. 5 give further information about the chemical distribution of some elements in both weathered concretes.

\section{Usual concrete weathered}

By comparison to the initial sample UC, several phases (portlandite, ettringite, calcium monosulfoaluminate and belite) disappeared during lixiviation and other mineral phases appear according to zones described in Tables I and II. The maps of distribution of chemical elements show us that the border of the sample is less rich in calcium, silicon than the core of the sample. Its content in sulphur seems to be zero. The border zone (zone 3 in Table I) spreads on 123 $\mu \mathrm{m}$ and is characterized by the crystallization of calcite and vaterite and the presence of hydrotalcite and hydrogarnet. Between the core of the sample and the border, two zones may be distinguished, one that is particularly rich in sulphur (zone 2 in Table I), between $128 \mu \mathrm{m}$ and $313 \mu \mathrm{m}$, where ettringite precipitates and another zone (zone 1 in Table I), particularly rich in silicon, lying between 318 and $663 \mu \mathrm{m}$. This last zone 1 distinguishes itself by the presence of new formed and primary ettringite and abundance of silica-rich CSH. Other authors [1-8] observed the same thing, formation of the new ettringite following the dissolution of the calcium monosulfoaluminate

\section{The very high strength concrete VHSC weathered}

The central part of weathered VHSC samples seems to be intact. The part of samples that underwent modifications

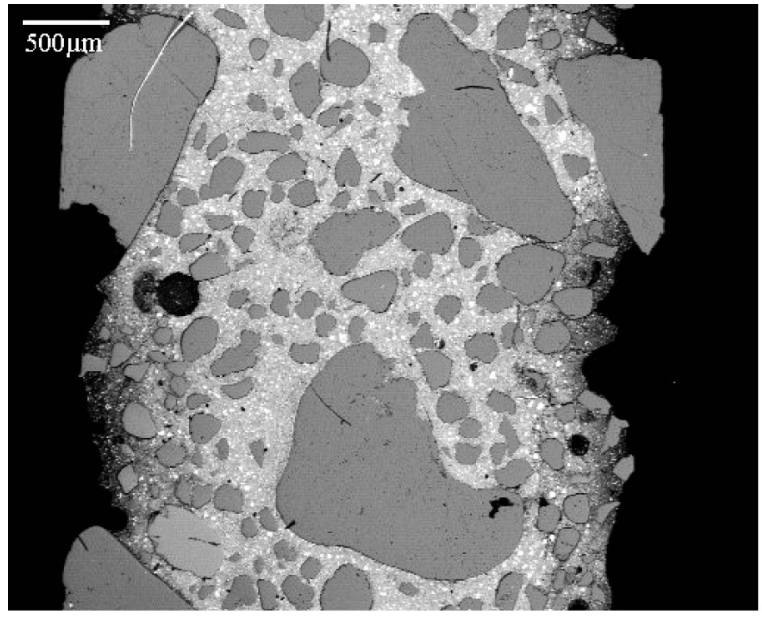

UC

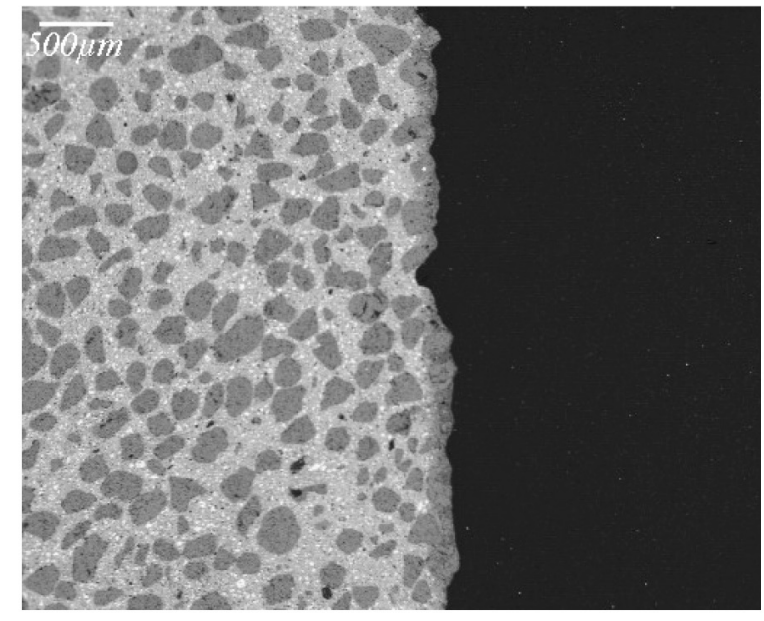

VHSC

Figure 3: Large-scale view by SEM of weathered UC and VHSC

[Figura 3: Vista em escala ampliada por microscopia eletrônica de varredura de concretos UC e VHSC climatizados.] 

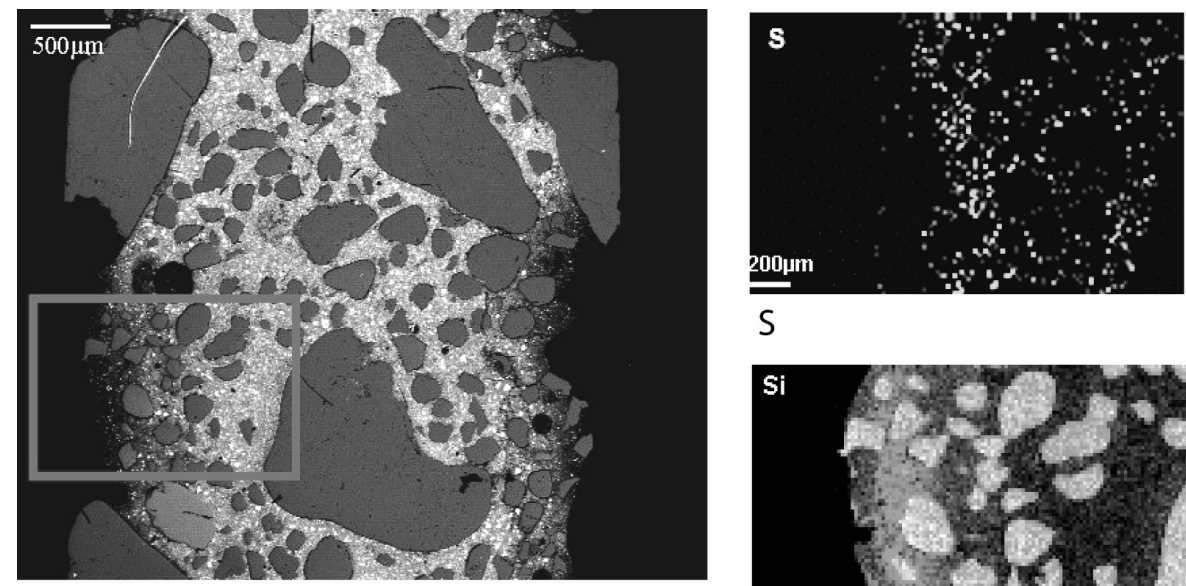

$\mathrm{S}$

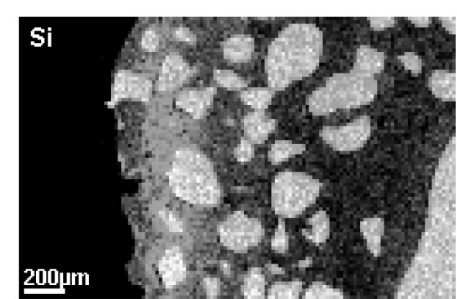

$\mathrm{Si}$

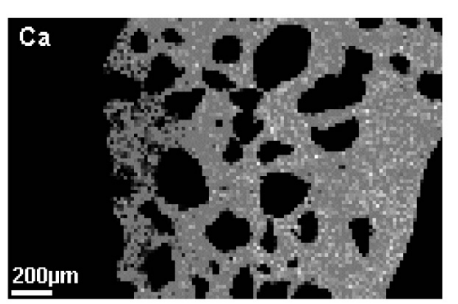

$\mathrm{Ca}$

Figure 4: Large-scale view of the weathered UC and distribution map of Ca, Si and S.

[Figura 4: Vista em escala ampliada por microscopia eletrônica de varredura de concreto UC climatizado e mapa de distribuição de Ca, Si e S.]
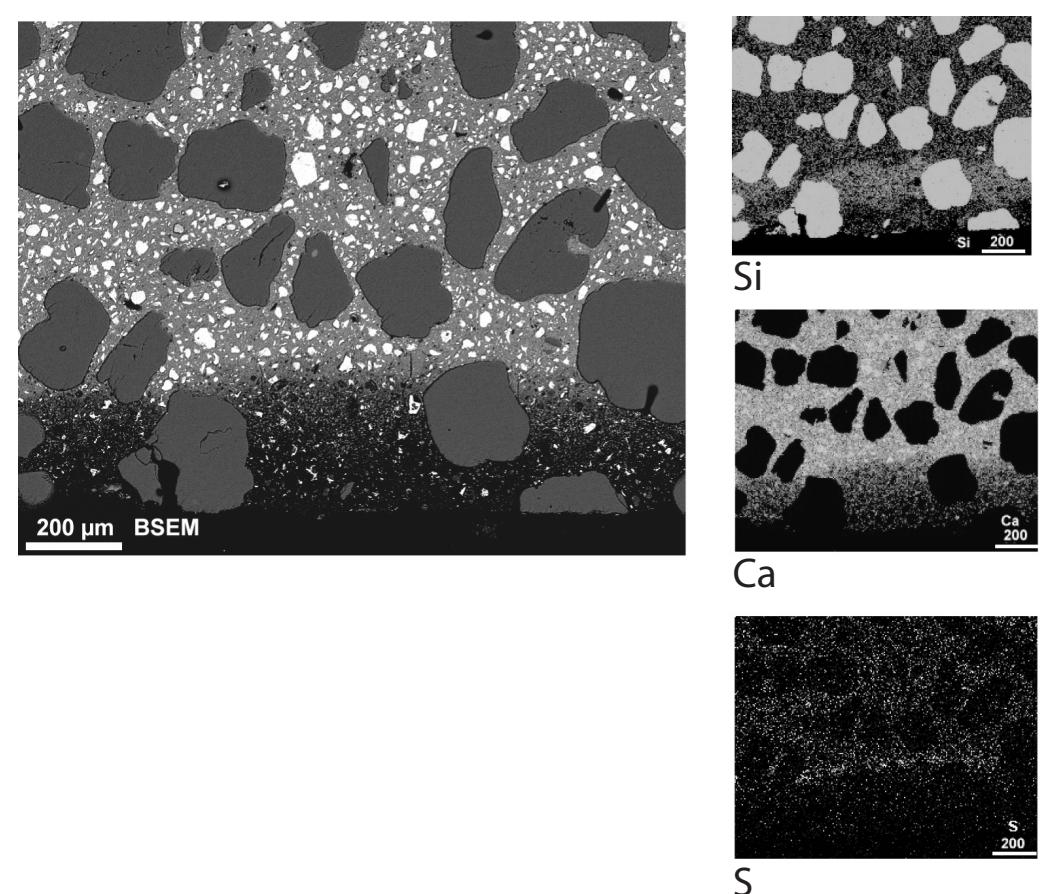

Figure 5: Large-scale view of the weathered VHSC and distribution map of Ca, Si and S. [Figura 5: Vista em escala ampliada por microscopia eletrônica de varredura de concreto VHSC climatizado e mapa de distribuição de Ca, Si e S.] 
Table I - XRD data for the zones of the weathered UC cement.

[Table I - Dados de difração de raios X das zonas do cimento climatizado.]

\begin{tabular}{lllll}
\hline UC & UC weathered & & & \\
\hline & Core & Zone 1 & Zone 2 & Zone 3 (rim) \\
\hline $\begin{array}{l}\text { Portlandite } \\
\text { Calcium }\end{array}$ & Portlandite & & Calcite & Calcite \\
Monosulfo-aluminate & $\begin{array}{l}\text { Calcium } \\
\text { monosulfo-aluminate }\end{array}$ & & & \\
$\mathrm{CSH}$ & $\mathrm{CSH}$ & $\mathrm{CSH}$ & $\mathrm{CSH}$ & $\mathrm{CSH}$ \\
$(1.2<\mathrm{C} / \mathrm{S}<2.3)$ & $(1.2<\mathrm{C} / \mathrm{S}<2.3)$ & $(0.9<\mathrm{C} / \mathrm{S}<1.9)$ & $(0.2<\mathrm{C} / \mathrm{S}<1.3)$ & $(\mathrm{C} / \mathrm{S} \approx 0,7)$ \\
& & Amorphous silica & Amorphous silica \\
Ettringite & Ettringite & Ettringite & Ettringite & \\
& Hydrogarnet & Hydrogarnet & Hydrogarnet & Hydrogarnet \\
Hydrogarnet & Hydrotalcite & Hydrotalcite & Hydrotalcite & Hydrotalcite \\
Hydrotalcite & Vaterite & Vaterite & Vaterite & Vaterite \\
& & & &
\end{tabular}

Utilização do planejamento experimental na incorporação do resíduo da indústria cerâmica em argamassas para obtenção da capacidade de retenção de água

\begin{tabular}{lllll}
\hline VHSC & Core & Zone 1 & Zone 2 & Zone 3 \\
\hline $\begin{array}{l}\text { Alite, Belite } \\
\text { Portlandite }\end{array}$ & $\begin{array}{l}\text { Alite, Belite } \\
\text { Portlandite }\end{array}$ & & \\
Ca Monosulfo-aluminate & & & \\
& & & \\
Ettringite & & & \\
CSH & $\mathrm{CSH}$ & Primary CSH & $\mathrm{CSH}$ & $\mathrm{CSH}$ \\
$(0.9<\mathrm{C} / \mathrm{S}<1.5)$ & $(0.9<\mathrm{C} / \mathrm{S}<1.5)$ & $\begin{array}{l}\text { Secondary } \mathrm{CSH} \\
(0.4<\mathrm{C} / \mathrm{S}<0.9)\end{array}$ & Amorphous silica & Amorphous silica \\
& & & & Hydrotalcite \\
\hline
\end{tabular}

represents a weak portion of samples; its thickness is of about $300 \mu \mathrm{m}$ compared to $800 \mu \mathrm{m}$ for UC. For the VHSC, the limit between the undamaged central part and the damaged part is marked by the dissolution of alite and portlandite. In the damaged part, three zones may be characterized by their composition and texture. When leaving from the core and while progressing toward the border of the sample, the first zone met is constituted in part of CSH with composition $0.9<$ $\mathrm{C} / \mathrm{S}<1.5$ and a similar texture to that of the core, and in part of new formed CSH $(0.4<\mathrm{C} / \mathrm{S}<0.9)$ in substitution to the alite. The second zone has a composition and a microstructure greatly heterogeneous. An agglomeration of newly formed $\mathrm{CSH}(0.4<\mathrm{C} / \mathrm{S}<0.9)$ is scattered among the primary CSH and mixed with amorphous silica. Alite disappeared in this zone, and has been replaced by the newly formed CSH. In the third zone, in the border of sample, the CSH have a composition and an organization more homogeneous than in the two previous zones. These CSH are newly formed, weakly calcic and mixed with amorphous silica.
Withdrawals of about $10 \mathrm{~mL}$ of solution from the reactor have been done regularly. For every withdrawal, the $\mathrm{pH}$ was measured and an analysis was made by ICP-AES for the content in $\mathrm{Ca}, \mathrm{Si}, \mathrm{Al}, \mathrm{Mg}, \mathrm{Na}$ and $\mathrm{K}$. We also determined the content in sulphates by ionic chromatography.

Solution of the reactor at the time of leaching the usual concrete UC

For the weathering of $\mathrm{UC}$, the $\mathrm{pH}$ is basic at the beginning (at about 11). Between 0 and 7 days, the $\mathrm{pH}$ decreases until it stabilizes at around 9 at the end of the experience. The $\mathrm{Ca}$, $\mathrm{Na}$ and $\mathrm{K}$ in the reactor seem to evolve as the square root of time. The washing out of $\mathrm{Ca}, \mathrm{Na}$ and $\mathrm{K}$ is made according to a diffusion mechanism. The washing out of $\mathrm{Si}, \mathrm{Al}, \mathrm{Mg}$ and sulphates is proportional to time, after a period of 7 day transition. These elements are added to the fluid thanks to dissolution of phases containing them. For the UC, the molar ratio $\mathrm{Ca} / \mathrm{Si}$ is raised at the beginning of the weathering 
process, and then it brutally drops from 6.6 to 2.3 between 0 and 14 days. Then, it slowly decreases from 2.2 to 0.51 from the 17th day until the end of the experiment. At the beginning of the weathering of the UC, Portlandite and the $\mathrm{CSH}$ with high $\mathrm{C} / \mathrm{S}$ ratio are dissolved. Then, the less calcic $\mathrm{CSH}$ are concerned.

Solution of the reactor at the time of leaching the very high strength concrete VHSC

The $\mathrm{pH}$ of the reactor solution during the weathering of VHSC remains constant at 10.8. Thus, the speciation of elements such as $\mathrm{Si}, \mathrm{Al}$ and $\mathrm{Fe}$ in solution does not evolve during the experiment. During the first twelve days, the evolution curve for $\mathrm{Ca}$ content being added to the solution is a linear function of time. But after 12 days, it evolves as the square root of time. The main mechanism for the liberation of calcium in solution is probably linked to the dissolution of grains of alite during the first twelve days, and then a diffusion mechanism becomes dominant. The $\mathrm{Na}$ and $\mathrm{K}$ contents evolve linearly according to time. Contrary to what we had observed with the pure paste, the mechanism of liberation of the alkali elements for VHSC weathering is not diffusion. Because of the weak hydration degree of the VHSC, the alkali elements are probably in the residual anhydrous grains. The $\mathrm{Si}, \mathrm{Al}, \mathrm{Mg}$ contents also evolve linearly with time. The curve of the sulphate ion liberation is also a linear function of time. By contrast, the calcium liberation curve evolves as the square root of time. For the VHSC, the molar ratio $\mathrm{Ca} / \mathrm{Si}$ is 4 at the beginning of the weathering process, and begins to decrease from the $12^{\text {th }}$ day on. It varies then from 3.6 to 2.2 at the $37^{\text {th }}$ day. After the $37^{\text {th }}$ day, the $\mathrm{Ca} / \mathrm{Si}$ ratio remains constant. In the case of the VHSC the value of $\mathrm{Ca} / \mathrm{Si}$ ratio at the beginning of the weathering is probably accounted for by the dissolution of the few present portlandite and alite grains. Then, it is probably the CSH that dissolve.

\section{CONCLUSIONS}

The samples of the very high strength concrete (VHSC) have been immersed in a reactor filled with continuously renewed water, under inert atmosphere. Previously, the same experience had been conducted with samples of usual concrete UC. Samples of VHSC contain very little water, and many grains of Alite cannot hydrate because of the lack of water. Their presence is due to a lack of water. So, when samples of VHSC are immersed in water, hydrated phases initially present in the VHSC are essentially the CSH $\beta$ type $(0.9<\mathrm{C} / \mathrm{S}<1.5)$. Some portlandite is also present, but in very weak quantity in relation to samples prepared without silica fumes. Ettringite and calcium monosulfoaluminate are also present in weak quantities because the Portland cement used for the confection of the VHSC is of class PM ES.
During the first 12 days of sample immersion in the reactor, the dissolution of alite seems to govern the release of calcium and silicon in the solution of the reactor. $\mathrm{Mg}, \mathrm{Al}, \mathrm{S}, \mathrm{Na}$ and $\mathrm{K}$ that were initially present as traces in the alite accompany the released calcium and silicon elements. After two months of experiment, we observed the modifications in VHSC samples with the same analytic tools as those used for UC samples. The central part of the weathered samples seems to be intact. The part of samples that underwent modifications represents a weak portion of samples. On a section of weathered VHSC, the damaged part has a thickness of about $300 \mu \mathrm{m}$, against $800 \mu \mathrm{m}$ in UC. For the VHSC, the limit between the non-damaged central part and the damaged part is marked by the dissolution of alite and of portlandite. In the weathered part, three zones with particular composition and texture were distinguished. As a conclusion, the low porosity of the very high strength concrete (VHSC) is a benefit for the compressive strength but also for the durability. The presence of numerous anhydrous clinker particles is not an inconvenient for the durability of VHSC samples.

\section{REFERENCES}

[1] B. Albert, "Altération de matrices cimentaires par des eaux de pluie et des eaux sulfatées : approche expérimentale et thermodynamique", Ph.D. Thesis, École N. S. des Mines de Saint-Etienne (2001) 294 p.

[2] B. Albert, E. Bilal, B. Guy, Tecbahia - Revista Baiana de Tecnologia 16, 1 (2001) 68.

[3] F. Adenot "Caractérisation et modélisation des processus physiques et chimiques de dégradation du ciment", Thèse, Université d'Orléans, France (1992).

[4] O. R. Batic, C. A. Milanesi, P. J. Maiza, S. A. Marfil, Cement Concrete Res. 30 (2000) 1407-1412.

[5] B. Bourdette "Durabilité du mortier: prise en compte des auréoles de transition dans la caractérisation et la modélisation des processus physiques et chimiques de l'altération", Thèse, INSA Toulouse, France (1994).

[6] P. Faucon "Durabilité du béton: physico-chimie de l'altération par de l'eau", Thèse, Université de CergyPontoise, France (1997).

[7] H. J. Kuzel, Cement Concrete Composites 18 (1996) 195-203.

[8] E. Moudilou "Cinétiques et mécanismes de relargage des métaux lourds présents en traces dans les matrices cimentaires", Thèse, Université d'Orléans, France (2000).

[9] K. Suzuki, T. Nishikawa, S. Ito, Cement Concrete Res. 15 (1985) 213-224.

[10] H. F. W. Taylor, J. Am. Ceram. Soc. (1950) 3682-3690. [11] I. Klur "Etude par RMN de la structure des silicates de calcium hydratés", Thèse, Université Paris VI, France (1996).

[12] A. Nonat, Bull. Liaison S.F.M.C. 12 (2000) 125.

(Rec.07/12/2007, Ac. /04/2008) 